\title{
A Discussion on Spatial Distribution Differentiation Law of Peanut Quality in China Based on GIS Technology
}

\author{
Liping Yang ${ }^{1}$, Honghai $\mathrm{Guo}^{2}$, Xinhua $\mathrm{Li}^{1}$, and Shubo Wan ${ }^{3}$ \\ ${ }^{1}$ Shan Dong Institute of Agriculture Sustainable Development, Jinan, Shandong, China \\ ${ }^{2}$ Agricultural Resources and Environment Institute of Shandong Provincial \\ Academy of Agricultural Sciences, Jinan, Shandong, China \\ ${ }^{3}$ Shan Dong Academy of Agricultural Sciences, Jinan, Shandong China \\ \{yangping96, honghaig,xinhuali_2008\}@163.com, wansb@saas.ac.cn
}

\begin{abstract}
In order to realize spatial differentiation law of peanut quality in China by quantitative analysis method based on GIS technology, a spatial analysis model for peanut quality was established based on 9 ecological factors influencing peanut quality (light, temperature, water and soil, etc). The results showed that it can be achieved in the analysis of peanut quality differentiation law in space with GIS technology. Taking peanut protein content as an example, the spatial distribution of peanut protein content gradually increases from north to south, high-content region distributes mainly in south of middle-lower Yangtze region; The results have instructive significance for production and breeding department to improve peanut protein quality, establish peanut special production base, optimize regional production layout, and provide a reference for quality rating and planting of other crops.
\end{abstract}

Keywords: Peanut quality, Protein content, GIS technology, Spatial distribution.

\section{Introduction}

Peanuts are major oil and food crops in the world, also major oil and cash crops in China. Since the 1990s, China's peanut production has ranked first around the world, accounting for about $1 / 3$ of global production. Peanuts are widely cultivated all over China, except for Qinghai and Ningxia [1,2].

The differences in peanut quality spatial distribution are formed under some ecological conditions, resulted from the combined effects of temperature, light, water, soil and other ecological factors which vary among regions, so geographical differences in peanut quality exist. Scholars at home and abroad mostly concern about species, farming systems and fertilizers related to peanut quality, however, there are contradictions such as regional imbalances, general purpose and special varieties, production and processing, so it is necessary to clarify the spatial distribution of peanut quality. As a result, Arcgis software is used to explore the spatial distribution of peanut quality based on ecological and geographical principles. In this paper, Peanut protein content, an important index of peanut quality, was used. A spatial analysis model for protein content is established based on 9 ecological factors influencing protein content, and spatial distribution of peanut protein 
content in China is analyzed by GIS technology. The results have instructive significance for production and breeding department to improve peanut protein quality, establish peanut special production base and optimize regional production layout.

\section{Spatial Analysis Model for Peanut Protein Content}

\subsection{Index System of Spatial Analysis Model for Peanut Protein Content}

Academic research suggests that temperature is the dominant factor influencing protein content whose accumulation is significantly positively correlated with temperature; as temperature rises, protein content increases [3]. During seedling stage, mild and moderate drought stresses can increase seed protein content, but severe drought conditions have little impact[4]; during pegging stage, drought has a larger impact on peanut protein: drought increases fat content but decreases protein content $[5,6]$; pod maturity, which determines peanut quality largely, is affected by accumulated temperature above $15^{\circ} \mathrm{C}[7]$; shading processing can reduce peanut crude protein content [8]; under similar climatic factors, soil type, texture and fertility levels become important factors determining peanut quality [9-11]. The spatial analysis model for peanut protein content is established based on 9 ecological factors influencing protein content, in which the meteorological factor only covers the whole growth period.

Table 1. Index system of peanut protein content analysis model

\begin{tabular}{|c|c|c|}
\hline Factors & & Interpretation \\
\hline \multirow{4}{*}{$\begin{array}{l}\text { Meteorological } \\
\text { factors }\end{array}$} & $\begin{array}{l}\mathrm{X}_{1}:>15^{\circ} \mathrm{C} \text { accumulated } \\
\text { temperature(the whole growth period } \\
\text { of peanut) }\end{array}$ & \multirow{4}{*}{$\begin{array}{l}>15^{\circ} \mathrm{C} \text { daily average temperature } \\
\text { accumulated during the whole } \\
\text { growth period of peanut } \\
\text { Precipitation accumulated during } \\
\text { the whole growth period of } \\
\text { peanut } \\
\text { Sunshine hours accumulated } \\
\text { during the whole growth period } \\
\text { of peanut } \\
\text { An average daily diurnal } \\
\text { variation of temperature during } \\
\text { the whole growth period of } \\
\text { peanut }\end{array}$} \\
\hline & $\begin{array}{l}\mathrm{X}_{2}: \text { Precipitation (the whole growth } \\
\text { period of peanut) }\end{array}$ & \\
\hline & $\begin{array}{l}\mathrm{X}_{3} \text { :Sunshine hours(the whole growth } \\
\text { period of peanut) }\end{array}$ & \\
\hline & $\begin{array}{l}\mathrm{X}_{4} \text { :Diurnal variation of } \\
\text { temperature(the whole growth period } \\
\text { of peanut) }\end{array}$ & \\
\hline \multirow{5}{*}{ Soil factors } & $\mathrm{X}_{5}$ : Soil organic matter & \multirow{4}{*}{$\begin{array}{l}\text { The data of sampling points of } \\
2008\end{array}$} \\
\hline & $\mathrm{X}_{6}$ : Soil $\mathrm{pH}$ & \\
\hline & $\mathrm{X}_{7}$ :Soil available phosphorus & \\
\hline & $\mathrm{X}_{8}:$ Soil available potassium & \\
\hline & $\mathrm{X}_{9}$ :Soil clay content & National $2 \mathrm{KM} \times 2 \mathrm{KM}$ grid data \\
\hline
\end{tabular}




\subsection{Data Source of Index System}

140 sampling points (sampling points are as shown in Fig. 1) were set in major peanut production areas of China, the pods and corresponding soil samples of dominant peanut cultivars were collected, and then pod protein content, soil organic matter, available phosphorus, available potassium, $\mathrm{PH}$, and other indexes were determined in accordance with national standards. The soil clay content is $2 \mathrm{KM} \times 2 \mathrm{KM}$ raster data from the Institute of Soil Science, Chinese Academy of Sciences[12,13]. Use extraction command in Arcgis9.2 software to extract the value of the sampling points.

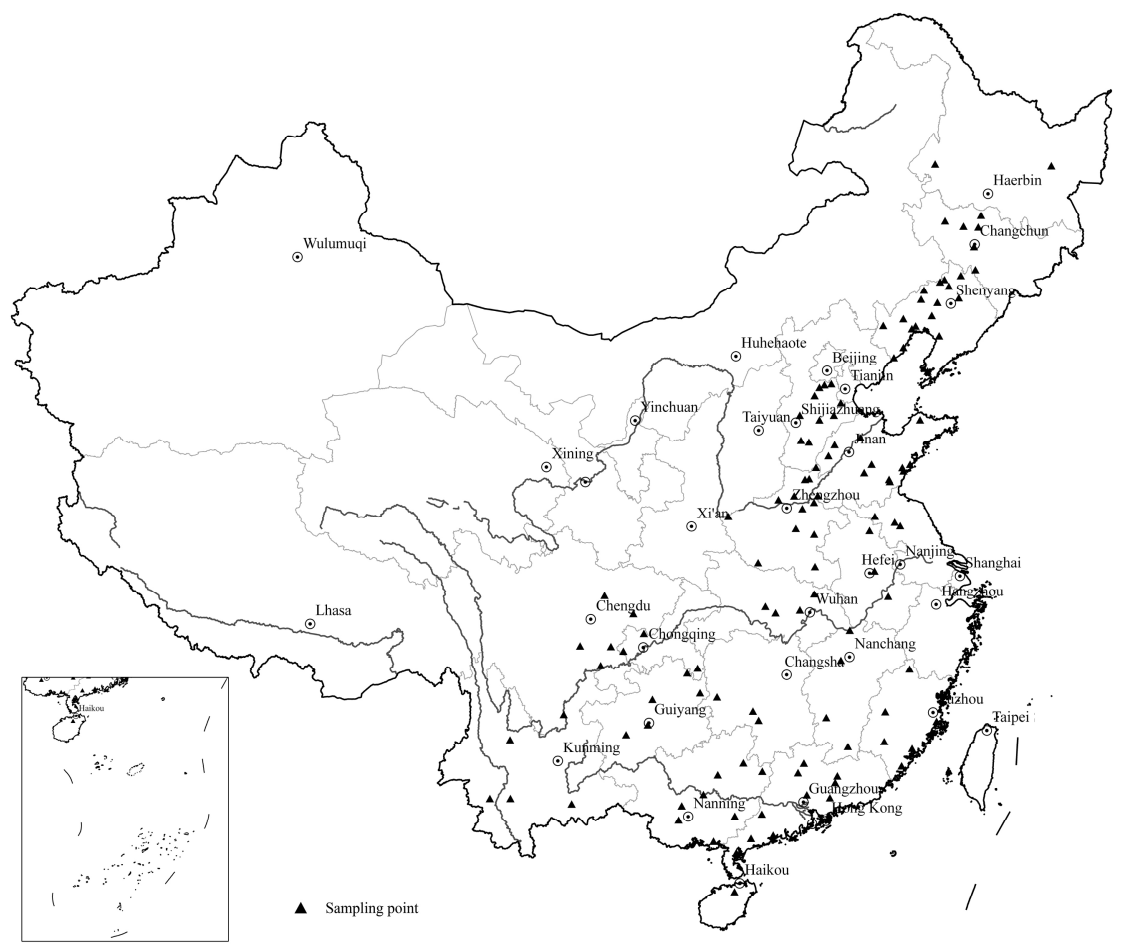

Fig. 1. Sampling points distribution map of 2008

Meteorological factors are provided by China Meteorological Data Sharing Service System, they are log data of 756 stations during peanut growth period. Process meteorological factors in Geostatistical Analyst module of Arcgis9.2 software, use ordinary Kriging method to calculate the spatial interpolation of meteorological factors at 756 points, and then use Extraction command to extract the data. 


\subsection{Analysis Model}

In spss13.0 software, Regression was used to establish the linear analytical model of peanut protein content, in which regression uses the enter method to include all factors into the equation. According to goodness-of-fit test of the model (Table 2) and ANOVA (Table 3), $\mathrm{R}=0.408, \mathrm{R}^{2}=0.166$, sig=0.046, the model passes the significance testing.

Table 2. Summary table of peanut protein content analysis model

\begin{tabular}{ccccc}
\hline Model & $\mathrm{R}$ & R Square & $\begin{array}{c}\text { Adjusted } \\
\text { R Square }\end{array}$ & $\begin{array}{c}\text { Std. Error of } \\
\text { the Estimate }\end{array}$ \\
\hline 1 & 0.408 & 0.166 & 0.084 & 2.311 \\
\hline
\end{tabular}

Table 3. ANOVA table of peanut protein content analysis model

\begin{tabular}{clccccc}
\hline \multirow{2}{*}{ Model } & & $\begin{array}{c}\text { Sum of } \\
\text { Squares }\end{array}$ & df & $\begin{array}{c}\text { Mean } \\
\text { Square }\end{array}$ & F & Sig. \\
\hline \multirow{2}{*}{1} & Regression & 97.051 & 9 & 10.783 & 2.02 & 0.046 \\
& Residual & 485.862 & 91 & 5.339 & & \\
& Total & 582.912 & 100 & & & \\
\hline
\end{tabular}

Linear regression model of peanut protein content is as shown below:

$\mathrm{Y}=32.432+0.0001 \mathrm{X}_{1}+0.00014 \mathrm{X}_{2}-0.00104 \mathrm{X}_{3}-0.30594 \mathrm{X}_{4}-0.04503 \mathrm{X}_{5}-0.33025 \mathrm{X}_{6}-0.027$

$15 \mathrm{X}_{7}-0.00351 \mathrm{X}_{8}+0.01884 \mathrm{X}_{9}$

\section{Spatial Analysis for Peanut Protein Content}

\subsection{Determination of Analysis Unit}

The analysis unit is required to indicate the spatial difference of peanut protein content. Each unit shall have its unique characteristics, including both variability and comparability. In the principle of quality consistency, this paper uses $2 \mathrm{KM} \times 2 \mathrm{KM}$ raster as the unit, and to enhance accuracy, all data were masked by 1:1000000 countrywide farmland vector layer, so only the farmland part was analyzed.

\subsection{Factor Processing}

Soil Factor Processing. Soil indexes are $2 \mathrm{KM} \times 2 \mathrm{KM}$ raster data from Institute of Soil Science of Chinese Academy of Sciences. 
Meteorological Factor Processing. The meteorological indexes are processed based on 30-year log data of peanut growth period during 1978-2007 (from 756 stations in China, provided by China Meteorological Data Sharing Service System). The $2 \mathrm{KM} \times 2 \mathrm{KM}$ raster data are acquired through Kriging interpolation calculation of the 756 stations' meteorological indexes under the Geostatistical Analyst module of Arcgis9.2.

Meteorological and soil factors are both masked by 1:1000000 countrywide farmland vector layer to obtain the farmland raster data.

Peanut Quality Spatial Distribution Analysis (based on protein content). Upon the Raster Calculator command of Spatial Analyst of Arcgis9.2, apply the model to carry out raster calculation, gain the value of each unit, which is protein content data for $2 \mathrm{KM} \times 2 \mathrm{KM}$ raster of countrywide farmland, thus the spatial distribution map for countrywide farmland is gained.

\section{$4 \quad$ Spatial Distribution Analysis for Peanut Quality}

Analyze the spatial distribution of peanut protein content for countrywide farmland with the classification function of Arcgis and the result shows a significant spatial distribution trend of peanut protein content: the minimum value which appears in Jilin Province is $13.3 \%$; the maximum value which appears in Taiwan Province is $32.9 \%$; the average value is $26.9 \%$. As shown in Fig. 2, the countrywide peanut protein content increases from south to north, with an average value of $28.3 \%$, higher value mainly in south of middle-lower Yangtze region, and slightly lower value in Inner Mongolia, Ningxia, Shaanxi, Gansu and Xinjiang, which is consistent with the research conclusion drawn by Xiao Changzhen etc. that peanut protein content is inversely related to the latitude [14].

\section{Discussion}

A spatial analysis model for peanut quality based on 9 ecological factors influencing protein content was established to analyze the spatial distribution of peanut quality in China (farmland), which breaks the old way of analyzing the relationship between peanut quality and environment on field scale and qualitatively describing spatial distribution of peanut quality.

It realizes quantitative analysis and point-to-dimension spatial analysis with GIS technology. As this research shows that the high-protein-content region mainly distributes in south of middle-lower Yangtze region, so production and breeding authorities shall give play to such areas, especially in southeast coastal areas, to make full use of the environment advantages, change the usage pattern of peanuts, extend the industrial chain of peanut protein, build peanut production bases and promote peanut industry development. The research result of this paper will provide a scientific theoretical basis for peanut quality classifying, strong breed selecting and planting, 


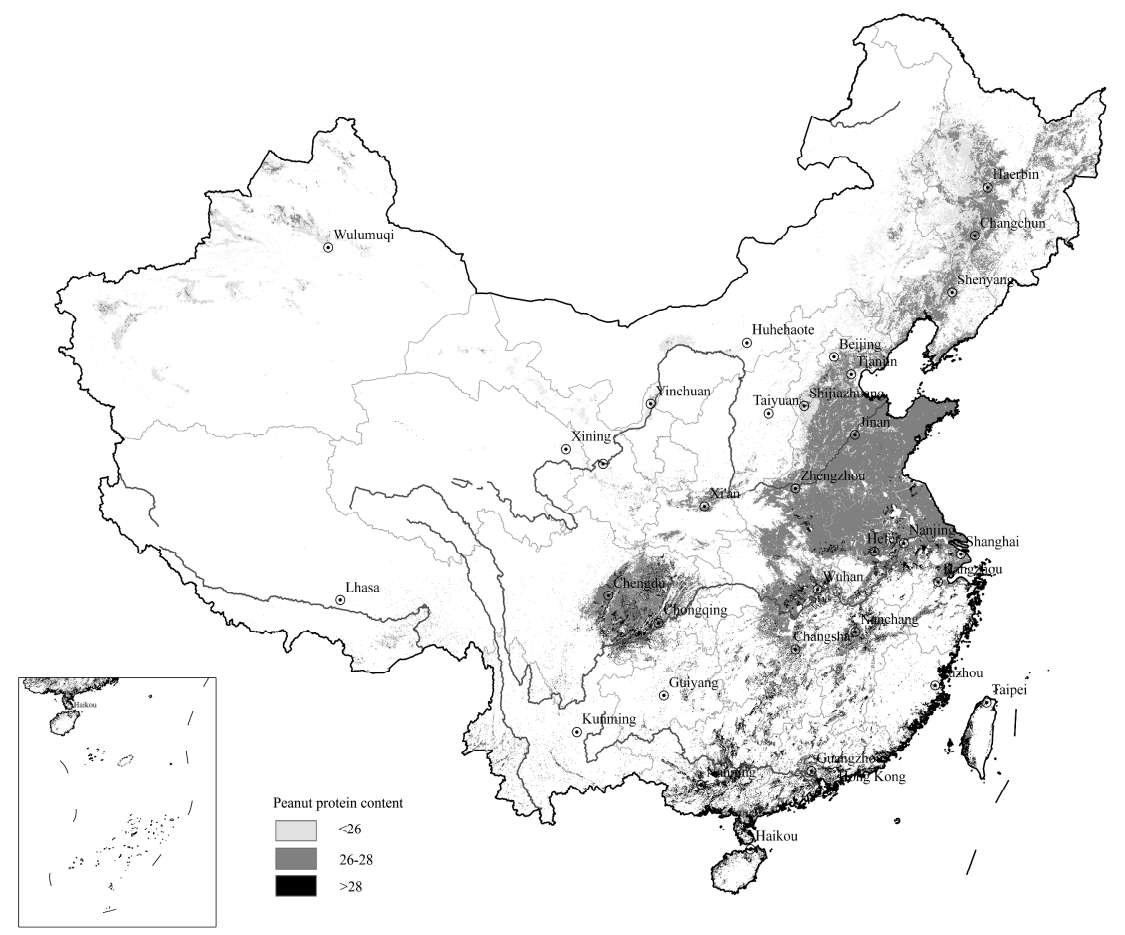

Fig. 2. Spatial distribution map of peanut protein content in China (cultivated land)

which will facilitate the implementation of the national policies of "setting up the sources of editable oils, vegetable proteins, raw materials, cash crops, and farmland biodiversity", to ensure oil crop safety and stable supply of high quality agricultural products.

The method of quantitatively analyzing spatial distribution of peanut quality with GIS technology discussed in this paper is scientific and feasible, but the accuracy of this model and the result needs to be further improved.

\section{References}

1. Yang, J.: Present Status and Outlook of Peanut Production and Trade in China. Journal of Peanut Science 38(1), 27-31 (2009)

2. Wan, S.: Peanut Quality Science. China Agricultural Science and Technology Publishing House, Beijing (2007)

3. Zhen, Z., Wang, X., Duan, Y., et al.: The Effect of Climatic Factors on Protein and Oil Content of Peanut Seeds. Journal of Peanut Science 33(3), 22-24 (2004)

4. Yan, M., Li, X., Lin, Y., et al.: Effects of Drought during Seedling Stage on Physiological Traits, Yield and Quality of Different Peanut Cultivars. Acta Agronomica Sinica 33(1), 113-119 (2007) 
5. Yao, J., Luo, Y., Yang, X., et al.: Study on peanut early variety critical moisture in different growth stages. Peanut Science and Technology 4, 23-27 (1982)

6. Yao, J., Yang, X.: Study on appropriate water of Summer Peanut. Peanut Science and Technology 2, 31-32 (1986)

7. Shi, K., Xue, X., Song, J., et al.: Preliminary study on meteorological condition of peanut quality. Peanut Science and Technology 1, 5-7 (1994)

8. Lin, C.H., McGraw, R.L., George, M.F., Garrett, H.E.: Nutritive Quality and Morphological Development under Partial Shade of Some Forage Species with Agroforestry Potential. Agroforesty Systems 53(3), 269-287 (2001)

9. Zhao, W., Jin, C.: Study on the low between peanut and soil texture. Peanut Science and Technology 3, 6-11 (1983)

10. Hu, W., Qiu, Q., Li, Z., et al.: Studies of the Effect Factors on Peanut Qualities II. Cultural Factors. Journal of Peanut Science 31(4), 14-18 (2002)

11. Zhang, J., Miao, H., Wu, L., et al.: The Impact of Different Soils and Fertilizers on Peanut Quality Traits. Journal of Peanut Science 32, 372-374 (2003)

12. Shi, X.Z., Yu, D.S., Warner, E.D., Sun, W.X., Petersen, G.W., Gong, Z.T.: Cross-Reference System for Translating Between Genetic Soil Classification of China and Soil Taxonomy. Soil Sci. Soc. Am. J. 70(1), 78-83 (2006)

13. Shi, X.Z., Yu, D.S., Warner, E.D., Pan, X.Z., Petersen, G.W., Gong, Z.G., Weindorf, D.C.: Soil Database of 1:1,000,000 Digital Soil Survey and Reference System of the Chinese Genetic Soil Classification System. Soil Survey Horizons 43(4), 129-136 (2004)

14. Xiao, C., Wu, Y., Gan, D., et al.: Analysis on Main Biochemical Quality of Peanut in China, pp. 161-166 (1999) 